\title{
Women empowerment- A challenge for Government as well as society
}

Autrhor for Correspondence:

Parul Gupta

Krishi Vigyan Kendra, Mohali (Punjab) India

Email : parulgupta145@gmail.

com
ABSTRACT : Women empowerment is the buzz word around the world, when it comes to ensuring women get equal opportunities as compared to men. This excitement around the topic is because of the potential women possess to contribute immensely to the development of society. This is because if a woman is empowered, then it is linked to the sustainable development in the entire world. Therefore, women empowerment has become important topic in the development of the nation. In order to make the nation developed, it is always necessary to developboth the halves of the population equally, i.e. the nation must ensure that both men and women are provided equal access to resources and opportunities to reach the ultimate goal of development. Empowering women means giving power to woman to take decisions at her own level in economic, political and all other dimensions of life.In order to empower women it is necessary to understand the ill practices followed by the society against women in male dominated Indian society. By and large they are discriminated against, suffer neglect, denied rights and violated in every possible way including getting killed even before they are born. The successive governments have been paying special attention to achieve the objectives of women empowerment. The government of India and Punjab has started so many programmes for the upliftment of the women. Ministry of women and child development has also started many schemes/programmes for the welfare of women. The governments have to be careful about not letting these schemes use women as only posters for the schemes. The women must be actual beneficiaries and for this the women themselves need to come forward and start coming out of the shadows of their family members. The schemes discussed in this paper clearly showed that govt. is providing all the help to women in order to achieve community, organizational, economic, political and psychological empowerment. Along with the governments it is our responsibility to be open-minded and change the mindset of the society by providing equal opportunities to women so that she performs well in all spheres of life. Keeping above points in mind, this paper made an attempt to analyze the need for women empowerment and various schemes launched by the state government for the benefit of women using secondary data sources.

KEY WORDS: Women empowerment, Government schemes, Female participation, Women, Child development

- HOW TO CITE THIS PAPER : Gupta, Parul (2020). Women empowerment- A challenge for Government as well as society. Asian J. Home Sci., 15 (1) : 164-170, DOI: 10.15740/HAS/AJHS/15.1/164-170. Copyright@ 2020: Hind Agri-Horticultural Society. 